\title{
Dynamic strength of end mills when processing wood and composite materials in panel house building
}

\author{
Alexander Sergeevichev*, Viktoria Sokolova, Artur Fedyaev and Vladimir Sergeevichev \\ Saint-Petersburg State Forest Technical University, Saint-Petersburg, Russian Federation
}

\begin{abstract}
The endurance of end mills during operation is determined by the bearing capacity of the working part of the housing and the wear resistance of the teeth. The bearing capacity of the working part is its ability to absorb the arising loads from the cutting forces and to provide rigidity and strength of mill. The required strength of end mills is determined by their design parameters and working conditions. A feature of the working conditions of end mills during the processing of chipboards and composite materials in panel house-building is that milling occurs with a depth of two cutting diameters. Therefore, at the most rational feeds on the tooth, the mills experience significant loads, leading to elastic extraction - bending of the working part and, often, to their breakage. During milling of chipboards and composite materials in panel house building, rapid wear and dulling of the side cutting edges of end mills is associated with uneven thickness of the processed materials. The presence in plates of more dense layers filled with binder causes zones of local intense wear. Thus, the presence of abrasive wear inclusions in plate and composite materials leads to rapid wear and dulling of the mill tooth, causes an increase in energy consumption during the milling process. The forces acting on the mill by the cutting resistance force cause elastic extraction of the spindle-mill system, friction of rear surfaces against the material being processed, that leads to the heating and breaking of mills. Hence, low bearing capacity and wear resistance of end mills determine their short durability.
\end{abstract}

\section{Introduction}

The efficient operation of end mills when processing wood products is possible only in the absence of large elastic deformations of the working part. The fulfillment of this condition is achieved by creating the necessary stress state in the mill body due to the geometric characteristics and operating modes [1-6]. The durability of end mills equipped with carbide inserts largely depends on matching between concentration of alternating stresses and fatigue characteristics of the mill body material, on the teeth wear and the period of their durability, as well as on the fastening strength of carbide cutting inserts. When studying the durability of end mills, it is necessary to consider such issues as the nature of the forces acting on the mill during operation by the resistance to cutting, lateral vibrations of mills and their elastic deformations in the spindle-mill system, as well as the shape of the elastic line during the extraction of the working part of the mill, contact conditions between the rear surfaces and the processed material [7-13].

\section{Methods}

The calculation methods for end mills developed by the authors [14-16] do not fully take into account the real conditions of their operation. Therefore, mills, calculated by the appropriate methods, are often brake down. The mentioned thesis is predominantly applied to mills, for which the ratio of its working depth to diameter is greater than one. For the correct calculation of end mills, it is necessary to know the alternating stress limit, exceeding which leads to the gradual accumulation of damage in the mill body and the formation of fatigue cracks. Due to the fact that dynamic stresses in mills exceed the static ones, it is better to calculate mills, according to the deformations from work process of end mills. For that, the relationship between deformations and displacements of mills, with respect to its axis, can be used. We assume that during the transition to the shank, the working part is rigidly fixed and there are no movements in it relative to the mill axis, according to the superposition principle on the element movements' independence in the system. The action plane of the resulting cutting forces $P_{\text {cut }}$ for all types of mills does not coincide with the direction of their cross-section's principal axes of inertia. Therefore, all types of end mills are sustained to biaxial bending stresses due to the cutting force. Additionally, the tangential component of the cutting force effect as a torque moment. The deformed state of mill from the action of bending moment caused by the tangent component of the cutting force, will be described by the deflection $v_{\mathrm{x}}$, Fig. 1. The deflection of mill $v_{x}$ will be equal to the vector sum of deflections $\omega$ and $u$ :

Corresponding author: 910sav@ gmail.com 


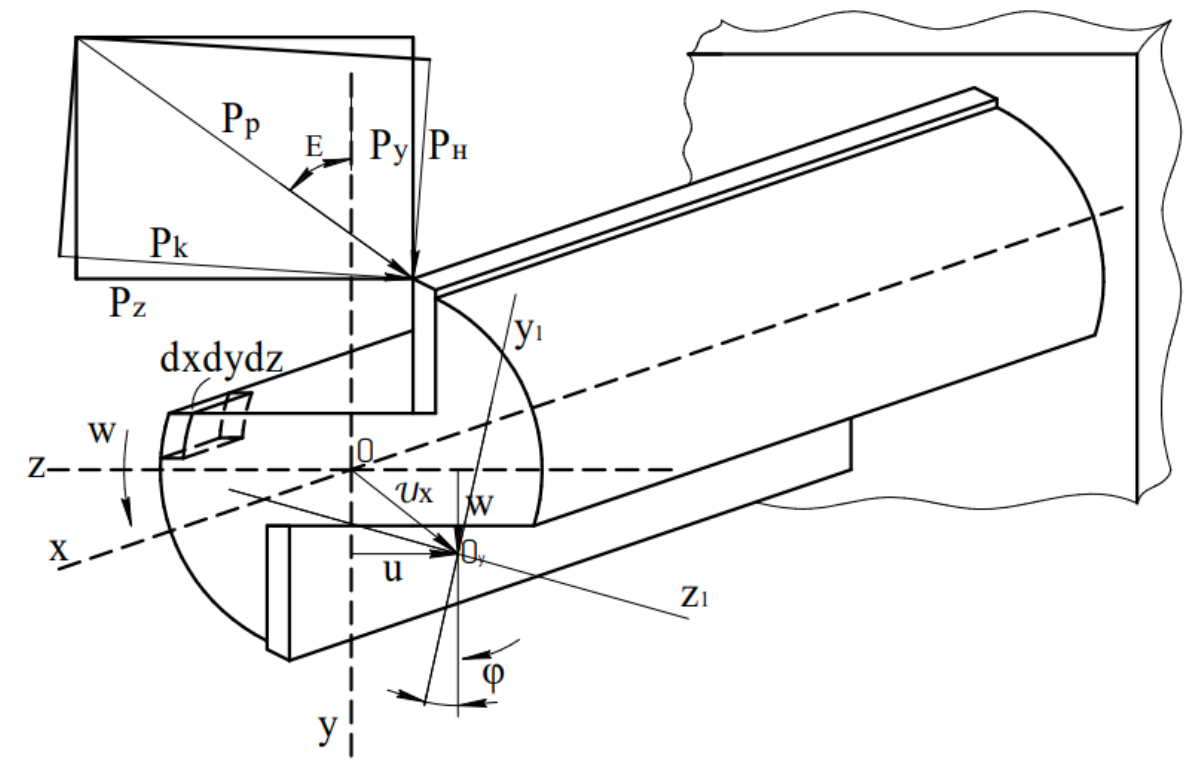

Fig. 1. The scheme for the end mill movement determination under the action of resistance to cutting force.

$$
v_{\mathrm{x}}=\sqrt{\omega^{2}+u^{2}}
$$

where: $\omega$ is the mill deflection in the direction of the principle axis OY, caused by the cutting force component $P_{\mathrm{y}}, \mathrm{mm} ; u$ is the mill deflection in the direction of the $\mathrm{OZ}$ axis, caused by the cutting force component $P_{\mathrm{z}}, \mathrm{mm}$.

An infinitesimal element of $d x \cdot d y \cdot d z$ size in the surface layer of the mill housing was selected (Fig. 2a). Under the action of the bending moment, tensile stresses $\sigma_{\mathrm{x}}$ and tangential stresses $\tau_{\mathrm{xy}}=\tau_{\mathrm{yx}}$ arise in it, which are caused by the torque (Fig. 2b). Under the assumption that the mill elastic hysteresis is infinitely small, the Hooke's law can be used to determine the stresses:

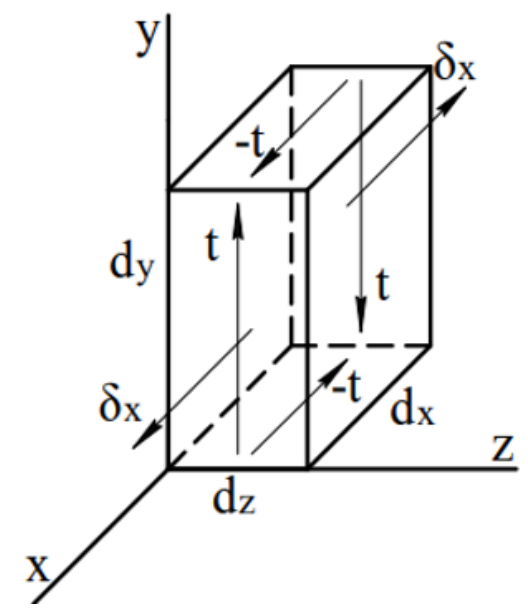

Fig. 2. The stresses at the end mill surface layer.

$$
\left\{\begin{array}{c}
\sigma=E \varepsilon_{\mathrm{x}}=E \cdot Z \cdot \frac{1}{\rho}=E \cdot Z \cdot \frac{\mathrm{d}^{2} v_{\mathrm{x}}}{\mathrm{d} x^{2}} \\
\tau=G \cdot \gamma_{\mathrm{y}}=G \cdot Z \cdot \frac{\mathrm{d} \varphi}{\mathrm{d} x}
\end{array}\right.
$$

where: $E ; G$ are the elasticity modulus of bending and torsion respectively, $\mathrm{MPa} ; \varepsilon_{\mathrm{x}} ; \gamma_{\mathrm{y}}$ are the relative deformation during bending and torsion, $\mathrm{m} ; Z$ is the distance from the chosen point to center of bending and torsion, $\mathrm{m}$.

In case of surface layer: $Z=\frac{d}{2}$.

$d$ is the mill housing diameter, $\mathrm{m}$.

$\varphi$ is the torsion angle, ${ }^{\circ}$.

The second derivative of the deflection $v_{\mathrm{x}}$ and the first derivative of the twist angle $\varphi$ can be determined from the differential equations of the deflection axis and the angular twist. According to $[17,18]$ we have:

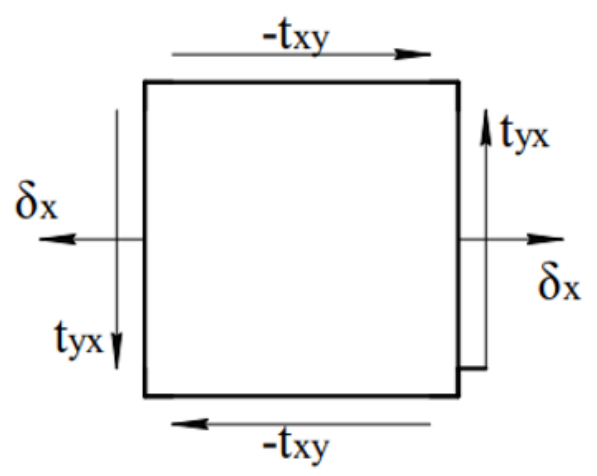




$$
\left\{\begin{array}{l}
\frac{\mathrm{d}^{2} v_{\mathrm{x}}}{\mathrm{d} x^{2}}=\frac{M(x)}{E \cdot J_{\mathrm{i}}} \\
\frac{\mathrm{d} \varphi}{\mathrm{d} x}=\frac{M_{\mathrm{K}}}{G \cdot J_{\mathrm{K}}}
\end{array}\right.
$$

Taking into account (3), system (2) takes the following form:

$$
\left\{\begin{array}{c}
\sigma(x)=\frac{M(x) \cdot Z}{J_{\mathrm{i}}} \\
\tau(x)=\frac{M_{\mathrm{K}} \cdot Z}{J_{\mathrm{K}}}
\end{array}\right.
$$

where $J_{\mathrm{i}}$ is the inertia moment of the mill section when bending relative to the normal to the axis of the cutting force action, $\mathrm{kg} \cdot \mathrm{m}^{2}$

Due to the fact that we are interested in the maximum stress in a critical section, the bending and torque moments can be expressed through the deflection and twist angle at the point $\mathrm{O}$ (Fig. 3), where the resulting cutting force is applied. Using theory of material strength equations, we have:

$$
\left\{\begin{array}{l}
M_{\mathrm{i}}=\frac{v_{0} \cdot 3 E \cdot J_{i}}{l^{2}} \\
M_{\mathrm{K}}=\frac{\varphi_{0} \cdot G \cdot J_{\mathrm{K}}}{l}
\end{array}\right.
$$

In equation system (5) 1 is determined according to fig. 3 as:

$$
l=\frac{H}{2}+l_{\mathrm{m}}
$$

where: $\frac{H}{2}$ is the half processing depth, $\mathrm{m} ; l_{\mathrm{m}}$ is the free mill length, $\mathrm{m}$.

By substituting (5) in (4), stress at any point in the critical section can be determined by:

$$
\left\{\begin{array}{c}
\sigma=\frac{3 E \cdot Z \cdot v_{0}}{l^{2}}=\frac{3 \cdot E \cdot Z \cdot v_{0}}{\left(\frac{H}{2}+l_{\mathrm{m}}\right)^{2}} \\
\tau=\frac{G \cdot Z \cdot \varphi_{0}}{l}=\frac{G \cdot Z \cdot \varphi_{0}}{\left(\frac{H}{2}+l_{\mathrm{m}}\right)}
\end{array}\right.
$$

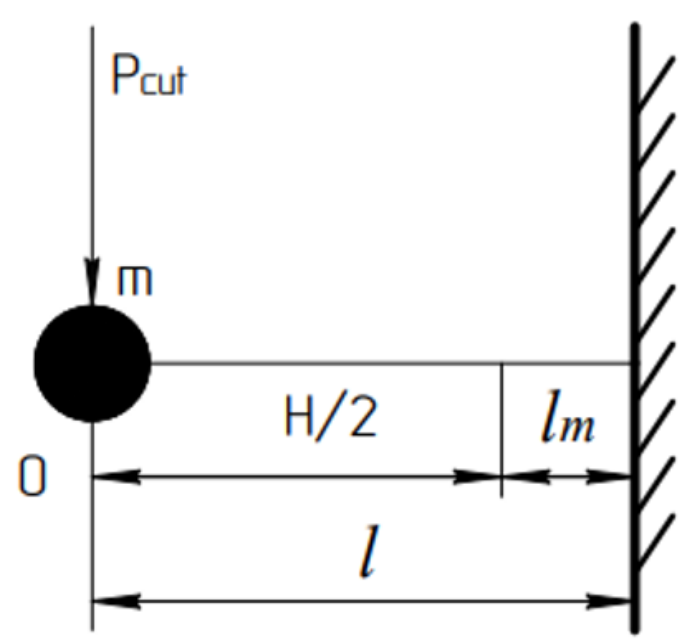

Fig. 3. The scheme of mill displacement under the action of cutting force at the point of its application.

In expressions (6), the deflection and the twist angle should be defined. To completely take into account the operating conditions of mill, we define them in dynamic regime. The oscillatory process of mill operation will be described by two equations characterizing the flexuraland-torsional vibrations Based on the general equation of motion for oscillations of a system with one degree of freedom, according to [19], the equations will have the form:

$$
\left\{\begin{array}{l}
\ddot{v}+\omega_{\mathrm{i}}^{2} \cdot v=\frac{1}{m_{\mathrm{i}}} \cdot P_{\mathrm{cut}} \cdot \sin \omega t \\
\ddot{\varphi}+\omega_{\mathrm{k}}^{2} \cdot \varphi=\frac{1}{m_{\mathrm{K}}} \cdot P_{\mathrm{K}} \cdot \sin \omega t
\end{array}\right.
$$

where: $m_{\mathrm{i}}, m_{\mathrm{K}}$ is the reduced mass of the working part of the bending and torsion mill, $\mathrm{kg}$. It is defined by work ratio [20].

When the distributed mass of the working part of mill is reduced to the center concentrated one, it is determined from the ratio:

$$
M_{\mathrm{w}}=M_{\mathrm{m}}-M_{\text {end }}=M_{\mathrm{m}}-\pi \cdot r_{\text {end }}^{2} \cdot l_{\mathrm{end}} \cdot q
$$

where: $M_{\mathrm{end}}$ is the mill shack mass, $\mathrm{kg} ; q$ is the mill housing material density, $\mathrm{kg} / \mathrm{m}^{3} ; l_{\text {end }}$ is the shack length, $\mathrm{m} ; r_{\text {end }}$ is the shack radius, $\mathrm{m} ; M_{\mathrm{m}}$ is the mill total mass, $\mathrm{kg}$.

$$
\left\{\begin{array}{l}
v=C_{1} \cdot \cos \omega_{\mathrm{i}} t+C_{2} \cdot \sin \omega_{\mathrm{i}} t+ \\
+\frac{P_{p}}{m_{i}} \cdot \frac{1}{\left(\omega_{\mathrm{i}}^{2}-\omega^{2}\right)} \sin (\omega t-\varphi) \\
\varphi=C_{1} \cdot \cos \omega_{\mathrm{k}} t+C_{2} \cdot \sin \omega_{\mathrm{k}} t+ \\
+\frac{P_{k}}{m_{\mathrm{k}}} \cdot \frac{1}{\left(\omega_{\mathrm{k}}^{2}-\omega^{2}\right)} \sin (\omega t-\varphi)
\end{array}\right.
$$


where: $\omega_{\mathrm{i}} ; \quad \omega_{\mathrm{k}}$ are the mill working part eigenfrequencies, $\mathrm{s}^{-1}$.

At time moment $\mathrm{t}=0, v$ and $\varphi$ are equal to zero, and their derivations $\dot{v}$ and $\dot{\varphi}$ are also equal to zero. Then the mill movement and the twist angle will be determined exclusively by forced oscillations of the working part

$$
\left\{\begin{array}{l}
v=\frac{P_{\mathrm{cut}}}{m_{\mathrm{i}}} \cdot \frac{1}{\left(\omega_{4}^{2}-\omega^{2}\right)} \cdot \sin (\omega t-\varphi) \\
\varphi=\frac{P_{\mathrm{k}}}{m_{\mathrm{k}}} \cdot \frac{1}{\left(\omega_{\mathrm{k}}^{2}-\omega^{2}\right)} \cdot \sin (\omega t-\varphi)
\end{array}\right.
$$

$P_{\text {cut }}$ and $P_{\mathrm{K}}$ forces can be defined by:

$$
\left\{\begin{array}{c}
P_{\mathrm{cut}}=108 \cdot a_{\mathrm{n}} \cdot H_{\mathrm{Z} \max } \cdot H \cdot U_{\mathrm{n}}^{0.2} \\
P_{\mathrm{K}}=a_{\mathrm{n}} \cdot K_{\mathrm{Z} \max } \cdot H \cdot U_{\mathrm{n}}^{0.2}
\end{array}\right.
$$

where: $a_{\mathrm{n}}$ is the correction factor for density of the processed material and mills dulling; $U_{\mathrm{n}}$ is the feed for revolution, $\mathrm{mm} ; K_{\mathrm{Zmax}}$ is the maximum coefficient of mill teeth sharpness impact; $H_{Z \max }$ is the maximum cutting depth, mm.

In the equation system (9), the mill eigenfrequencies during bending and torsion are not defined. For cantilever bars, according to [21], they can be determined by the following equations:

during torsion:

$$
\omega_{\mathrm{k}}=\frac{\pi(2 K-1)}{2 l_{\mathrm{w}}} \cdot \sqrt{\frac{G \cdot J_{\mathrm{K}}}{q \cdot J_{\rho}}},
$$

during bending:

$$
\omega_{\mathrm{i}}=\frac{\pi(2 K-1)}{2 l_{\mathrm{w}}^{2}} \cdot \sqrt{\frac{E \cdot J_{\mathrm{i}}}{q \cdot F}},
$$

where $K$ is the sequential number of frequency; $l_{\mathrm{w}}$ is the mill working part length, $\mathrm{m} ; q$ is the mill material density, $\mathrm{kg} / \mathrm{m}^{3} ; J_{\rho}$ is the polar inertia moment during torsion.

$$
J_{\rho}=\int_{F} r^{2} \mathrm{~d} F \quad \text { or } \quad J_{\rho}=J_{\mathrm{y}}+J_{\mathrm{z}}
$$

where $F$ is the cross-section area, $\mathrm{m}^{2} ; J_{K}$ is the torsion inertia moment, $\mathrm{kg} \cdot \mathrm{m}^{2} ; J_{i}$ is the mill cross section inertia moment when bending axis coincide with the direction of cutting force vector, $\mathrm{kg} \cdot \mathrm{m}^{2}$.

Using the science of material strength, $J_{i}$ can be defined by:

$$
J_{\mathrm{i}}=J_{\mathrm{y}} \cdot \cos ^{2} \varepsilon+J_{\mathrm{z}} \sin ^{2} \varepsilon-\frac{\left(J_{\mathrm{y}}-J_{\mathrm{z}}\right) \operatorname{tg} 2 \varepsilon}{2} \sin 2 \varepsilon
$$

where $J_{\mathrm{y}}$ and $J_{\mathrm{z}}$ are the inertia moments relative to principal central axes, $\mathrm{kg} \cdot \mathrm{m}^{2} ; \varepsilon$ is the angle between resulting cutting force and $O Y$ axis, ${ }^{\circ}$.

The maximum displacement and twist angle will be at $\sin (\omega t-\varphi)=1$ They are defined as:

$$
\left\{\begin{array}{c}
v=\frac{P_{\mathrm{cut}}}{m_{\mathrm{i}}} \cdot \frac{1}{\left(\omega_{\mathrm{i}}^{2}-\omega^{2}\right)}=\frac{1.08 \cdot a_{\mathrm{n}} \cdot k_{\mathrm{zmax}} \cdot H \cdot U_{\mathrm{n}}^{0.2}}{M_{\mathrm{w}} \cdot\left(\omega_{\mathrm{i}}^{2}-\omega^{2}\right)} \\
\varphi=\frac{P_{\mathrm{K}}}{m_{\mathrm{k}}} \cdot \frac{1}{\left(\omega_{\mathrm{k}}^{2}-\omega^{2}\right)}=\frac{a_{\mathrm{n}} \cdot k_{\mathrm{zmax}} \cdot H \cdot U_{\mathrm{n}}^{0.2}}{M_{\mathrm{w}} \cdot\left(\omega_{\mathrm{k}}^{2}-\omega^{2}\right)}
\end{array}\right.
$$

By substituting equations (14) into system (6), stress at any point in the critical section can be determined by:

$$
\left\{\begin{array}{c}
\sigma=\frac{3.2 \cdot E \cdot Z \cdot a_{\mathrm{n}} \cdot k_{\mathrm{Zmax}} \cdot H \cdot U_{\mathrm{n}}^{0.2}}{\left(\frac{H}{2}+l_{\mathrm{m}}\right)^{2} \cdot\left(\omega_{\mathrm{i}}^{2}-\omega^{2}\right) \cdot M_{\mathrm{w}}} \\
\tau=\frac{G \cdot Z \cdot a_{\mathrm{n}} \cdot k_{\mathrm{Zmax}} \cdot H \cdot U_{\mathrm{n}}^{0.2}}{M_{\mathrm{w}} \cdot\left(\omega_{\mathrm{k}}^{2}-\omega^{2}\right) \cdot\left(\frac{n}{2}+l_{\mathrm{m}}\right)}
\end{array}\right.
$$

The stresses in the critical section can be determined depending on the distance $\mathrm{Z}$, which shows the position of the selected point. Maximum stress will be on the surface of the mill hosing. For different mills types, the distance $\mathrm{Z}$ is determined depending on the design parameters, and especially on the inclination angle of front face plane relative to the principal central axes of inertia.

Having determined stresses in the critical section, the end mills fatigue strength will be calculated. A feature of mills operation is that their stresses amplitudes change in time from minimum to maximum as they are dulling. A set of stress amplitudes for the period of mills endurance will be the loading unit $[21,22]$. The particularity of loads in the block is that the stress amplitudes do not increase continuously, but with "rest pauses" when idling, stopping the machine-tool, etc. Due to the fact that the stress amplitudes in time will depend on the level of mills dulling, their distribution function can be presented as a change in energy indicators of milling with respect to the radius of curvature of the mill cutting edges. According to the data on mills dulling [10-12], the distribution law of normal $\sigma$ and tangential $\tau$ stress amplitudes will be exponential. The number of load blocks over the mill life will depend on the number of regrinding and restoration by resoldering.

\section{Results and Discussion}

In accordance with the corrected linear hypothesis of the fatigue damage summation [22], we determine the destructive number of load blocks by tangential and normal stresses. Due to exponential law of the stress amplitudes distribution in the block, we have: 


$$
\lambda=\frac{a_{\mathrm{p}} \cdot N_{0} \cdot X_{0}^{m} \cdot 2^{m-1}}{\gamma_{\sigma} \cdot \psi(2 m+2) \cdot P\left(2 x_{0} ; 2 m+2\right)}
$$

where: $x_{0}=\frac{\sigma_{-1 D}}{\sigma_{a}}$ or $x_{0}=\frac{\tau_{-1 D}}{\tau_{a}}$ is the end mill endurance limit ratio for normal and tangential stresses to the limiting cycle amplitudes; $N_{0}$ is the number of cycles, corresponding to fatigue curve fracture point; $m$ is the fatigue curve parameter, characterizing left branch slope; $P\left(2 x_{0} ; 2 m+2\right)$ is the tabulated function of probability integral.

The $\psi(2 m+2)$ is defined as:

$$
\psi(n)=\left\{\begin{array}{c}
(n-2) \cdot \sqrt{\frac{\pi}{2}} \\
2^{\frac{n}{2}-1}\left(\frac{n}{2}-1\right) !
\end{array}\right. \text { with odd and evenn, respectively }
$$

$a_{\mathrm{p}}$ is the coefficient, which corrects the linear hypothesis of damage summation; for the exponential law of stress amplitudes distribution in the block it is

$$
a_{\mathrm{p}}=\frac{\frac{P\left(2 Y_{0} ; 4\right)}{P\left(2 Y_{0} ; 2\right)}}{12-Y_{0}}-Y_{0}
$$

where:

$$
Y_{0}=\frac{0.5 \sigma_{-1 D}}{\bar{\sigma}_{a}} \text { or } Y_{0}=\frac{0.5 \tau_{-1 D}}{\overline{\bar{\tau}}_{a}}
$$

$\gamma_{\sigma}$ is the total number of repetition cycles of all level amplitudes in the load block, which is determined as:

$$
\gamma_{\sigma}=t_{\mathrm{e}} \cdot n_{\mathrm{m}}
$$

where $t_{\mathrm{e}}$ is the mill endurance period according to machine time, $\min ; n_{\mathrm{m}}$ is the mill rotation frequency, $\min ^{-1}$.

It is recommended to present the density function of the stress amplitudes exponential distribution in the form:

$$
f\left(\sigma_{\mathrm{a}}\right)=\frac{1}{\bar{\sigma}_{\mathrm{a}}} \cdot \mathrm{e}^{-\left(\frac{\sigma_{\mathrm{a}}}{\bar{\sigma}_{\mathrm{a}}}\right)}
$$

Fatigue curve parameter $m$ can be found as:

$$
m=\frac{\lg \frac{N_{0}}{N}}{\lg \frac{\sigma_{\mathrm{a}}}{\sigma_{-1}}} \text { or } m=\frac{c}{K_{\sigma \mathrm{D}}}
$$

where: $c \approx 18$ for alloyed steel; $k_{\sigma \mathrm{D}}$ is the total coefficient taking into account the influence of all factors on fatigue resistance;

$$
K_{\sigma \mathrm{D}}=\frac{\sigma_{-1}}{\sigma_{-1 \mathrm{D}}}=\frac{k_{\sigma}}{\mathrm{e}_{\sigma}}+\frac{1}{\beta}-1
$$

where: $\sigma_{-1 \mathrm{D}}$ is the end mill endurance limit in a symmetrical cycle; $\beta$ is the processing quality coefficient; $\beta \approx 0.5 ; K_{\sigma}$ is the effective concentration coefficient; for end mills $K_{\sigma}=1.8 ; e_{\sigma}$ is the coefficient of mill cross-section area impact;

$$
\mathrm{e}_{\sigma} \approx 0.96 \text { if } D=16 \mathrm{~mm} \text {. }
$$

For practical calculations of end mills endurance, one can take $K_{\sigma \mathrm{D}} \approx 2.8-3.2$. Based on (22) $m$ is assumed to be equal to 6 .

Further we determine the value $\psi(2 m+2)$ :

$$
\psi(14)=2^{\frac{14}{2}-1}\left(\frac{14}{2}-1\right) !=46 \cdot 10^{3}
$$

The mills fatigue endurance by normal stresses can be expressed through the material endurance limit. From the equation (22):

$$
\sigma_{-1 \mathrm{D}}=\frac{\sigma_{-1}}{K_{\sigma \mathrm{D}}}=\frac{\sigma_{-1}}{2,9}=0.34 \sigma_{-1}
$$

Due to the fact that the influence of all factors on the fatigue resistance during bending and torsion is insignificant, we can write an expression similar to that for normal stress: $\tau_{-1 \mathrm{D}}=0.34 \tau_{-1}$

Then

$$
\left\{\begin{array} { l } 
{ X _ { 0 } = \frac { 0 . 3 4 \sigma _ { - 1 } } { \overline { \sigma } _ { \mathrm { a } } } } \\
{ Y _ { 0 } = \frac { 0 . 1 7 \sigma _ { - 1 } } { \overline { \sigma } _ { \mathrm { a } } } }
\end{array} \text { or } \left\{\begin{array}{l}
X_{0}=\frac{0.34 \tau_{-1}}{\bar{\tau}_{\mathrm{a}}} \\
Y_{0}=\frac{0.17 \tau_{-1}}{\bar{\tau}_{\mathrm{a}}}
\end{array}\right.\right.
$$

Taking the number of cycles $N_{0}=10^{7}$ and taking into account the performed calculations, expression (16) can be rewritten in the following form:

$$
\left\{\begin{array}{l}
\lambda_{\sigma}=7 \cdot 10^{3} \frac{a_{\mathrm{w}} \cdot X_{0}^{6}}{\gamma_{\sigma} \cdot P\left(2 X_{0} ; 6\right)} \\
\lambda_{\sigma}=7 \cdot 10^{3} \frac{a_{\mathrm{w}} \cdot X_{0}^{6}}{\gamma_{\tau} \cdot P\left(2 X_{0} ; 6\right)}
\end{array}\right.
$$

In equations system (24), it is necessary to use the corresponding values of the load factors $X_{0}$ and $Y_{0}$ for determination the correction coefficient $a_{\mathrm{w}}$ and the probability integral $P(X ; Y ; n)$.

Upon condition that $m_{\sigma}=m_{\tau}=m$, the total resource of end mills operation under the simultaneous action of tangential and normal stresses, expressed in the quantities of their installations in the working machine, was determined from the expression: 


$$
\lambda=\frac{\lambda_{\sigma} \cdot \lambda_{\tau}}{\left(\lambda_{\sigma}^{\frac{2}{m}}+\lambda_{\tau}^{\frac{2}{m}}\right)^{\frac{m}{2}}}=\frac{\lambda_{\sigma} \cdot \lambda_{\tau}}{\left(\lambda_{\sigma}^{0.33}+\lambda_{\tau}^{0.33}\right)^{3}}
$$

Thus, the main ways to increase the end mills service life upon fatigue damages are the following: reducing stress levels, increasing the fatigue characteristics of the housing material, reducing the stress concentration in a critical section, improving the surface quality of housing.

\section{Conclusions}

1. During operation, the end mill stresses are not constant, but increase from minimum to maximum. The stress density distribution law is exponential for their increase. The load block is the set of all level stress amplitudes during mill work till dulling. The number of milling load blocks during operation corresponds to the number of regrindings and their settings in the working machine.

2. Using the corrected linear hypothesis of the fatigue damage summation and taking into account all load cycles, the life of the mill housing to failure can be predicted.

3. The durability of end mills during operation depends on two factors: the housing bearing capacity and the teeth abrasion hardness. Their influences on durability are not equivalent. Increasing the bearing capacity of the mill housing will increase a tooth feed, thereby reducing the cutting path per unit length of the treatable groove. In addition, equipping mills with high resistance cutting materials will increase their fatigue characteristics.

\section{References}

1. Potapova M.S., Vinogradov D.V. Overview of curved mills [Obzor frez s krivolineynoy rezhushchey kromkoy] Nauka i obrazovanie. Nauchnoe izdanie Moskovskogo gosudarstvennogo tekhnicheskogo universiteta imeni N.E. Baumana. Moscow, 2014. Is. 11. Pp. 21-33. (In Russ.)

2. Morozov V.G. Wood cutting tool. Handbook [Derevorezhushchiy instrument. Spravochnik]. Moscow, 1988, 332 p. (In Russ.)

3. Glebov I.T. Woodcutting tools [Derevorezhushchij instrument]. Yekaterinburg: USFTU, 2001. 197 p. (In Russ.)

4. Zotov G.A. Woodcutting tools. Construction and operation [Derevorezhushchij instrument. Konstrukciya i ekspluataciya]. SPb.: "Lan'”, 2010. 384 p. (In Russ.)

5. Sanev V.I., Kamenev B.B., Sergeevichev A.V. Cutting wood and wood materials [Rezaniye drevesiny i drevesnykh materialov] SPb.: "Lan", 2018. 456p. (In Russ.).

6. Amalitsky V. V., Amalitsky V. V. Inventory of branch [Oborudovanie otrasli]. Moscow: GOU MGUL, 2005. 560 p. (In Russ.)
7. Vereshchagin V.Yu., Mokrickij B.Ya., Vereshchagina A.S. Analysis of composite end mill test results [Analiz rezul'tatov ispytanij sostavnyh koncevyh frez]. Uchenye zapiski Komsomol'skogo na Amure gosudarstvennogo tekhnologicheskogo universiteta, 2016, Vol.1, is.3 (27), pp. 53-56. (In Russ.)

8. Glebov I.T. Cutting of wood [Rezanie drevesiny]. SPb.: "Lan", 2010. 256p. (In Russ.)

9. Zotov G.A. Machine tools for woodcutting [Stanochnyj derevorezhushchij instrument]. Moscow, 2005. 307 p. (In Russ.)

10. Kamenev B. B., Sergeevichev A. V. Woodcutting tools [Derevorezhushchie instrument]. SPb.: SPbGLTU, 2013. 330 p. (In Russ.)

11. Usachev P.A., Parkhomenko S.G. Increased wear and tear of cutting tools [Povysheniye iznosostoykosti i prochnosti rezhushchikh instrumentov]. Kiev, 1988. 156 p. (In Russ.)

12. Loladze T.N. Strength and wear resistance of the cutting tool [Prochnost' i iznosostojkost' rezhushchego instrumenta]. Moscow, 1987, 320 p. (In Russ.)

13. Bachmann G., Fischer R., Habber W. Holzbearbeitung. Leipzig: Fachbunchvert, 1994. 500 p.

14. Kim A.B. Analysis of the geometric parameters of prefabricated end mills with interchangeable polyhedral plates [Analiz geometricheskih parametrov sbornyh koncevyh frez so smennymi mnogogrannymi plastinami] Progressivnye tekhnologii i ekonomika v mashinostroenii. Trudy II Vserossijskoj nauchnoprakticheskoj konferencii, 2004. Pp. 84-88. (In Russ.)

15. Savolov A.V., Nikolaev D.Yu., Nikolaev A.Yu. Study of the influence of the imbalance of tool settings on the output indicators of milling [Issledovaniye vliyaniya disbalansa instrumental'nykh naladok na vykhodnyye pokazateli frezerovaniya] Vestnik Irkutskogo gosudarstvennogo tekhnologicheskogo universiteta. Irkutsk, 2015. Is. 7(102). Pp. 81-91. (In Russ.)

16. Egodurov G.S., Bochetkueva E.B. About mechanical testing of materials in the course of resistance of materials [O mekhanicheskih ispytaniyah materialov v kurse soprotivleniya materialov] Sbornik nauchnyh trudov. Seriya: mekhanika konstrukcij i materialov. Kompozicionnye materialy i nanomaterialy, 2016. Pp. 123-130. (In Russ.)

17. Logvinov V.B., Evtushenko S.I., Kaznacheeva O.K., Petrov I.A. Reference materials for design and engineering work on the resistance of materials, construction and applied mechanics [Spravochnye materialy $\mathrm{k}$ raschetno-proektnym rabotam po soprotivleniyu materialov, stroitel'noj i prikladnoj mekhanike]. The 3 rd edition. Novocherkassk, 583 p. (In Russ.)

18. Timoshenko S.P., Goodyear D. Theory of Elasticity [Teoriya uprugosti]. Moscow, 1985. 575 p. (In Russ.)

19. Bachmann G., Fischer R., Habler W. Holzbearbeitung. Leipzig: Fachbuchverl, 1994. 500 p.

20. Ostaf'yev V.A. Calculation of the dynamic strength of the cutting tool [Raschet dinamicheskoy prochnosti rezhushchego instrumenta]. Moscow, 1989, 168 p. (In Russ.) 
21. Kapralov V.M., Kopen'ko G.S. Influence of loading frequencies on material fatigue resistance [Vliyanie chastot nagruzheniya na soprotivlenie ustalosti materialov] Nauchno-tekhnicheskie vedomosti SPbPU. Estestvennye i inzhenernye nauki. Vol. 25. Is.2, 2019. Pp.68-72. (In Russ.)

22. Tarankova E.S., Sosnovskij L.A. The influence of the working environment on the fatigue resistance of materials: a review of studies [Vliyanie rabochej sredy na soprotivlenie ustalosti materialov: obzor issledovanij] Vestnik Belorusskogo gosudarstvennogo universiteta transporta: Nauka i transport. Minsk. Is. 2(23), 2011. Pp. 87-90. (In Russ.) 